\title{
Cocaine opens the blood-brain barrier to HIV-1 invasion
}

\author{
Ling Zhang ${ }^{1}$, David Looney ${ }^{3}$, Dennis Taub ${ }^{4}$, Sulie L Chang ${ }^{5}$, Dennis Way ${ }^{6}$, Marlys H Witte ${ }^{6}$, Michael C Graves ${ }^{1}$ \\ and Milan Fiala ${ }^{2}$ \\ Departments of ${ }^{1}$ Neurology and ${ }^{2}$ Medicine, UCLA School of Medicine, Los Angeles, California 90095-1769; ${ }^{3}$ Infectious \\ Diseases 9-111F, VA San Diego Healthcare Center, San Diego, California 92161; ${ }^{4}$ National Institute on Aging, Baltimore, \\ Maryland 21224-2780; ${ }^{5}$ Department of Biology, Seton Hall University, South Orange, New Jersey 07079-2694; and \\ ${ }^{6}$ Department of Surgery, University of Arizona, Tucson, Arizona 85724-5063, USA
}

\begin{abstract}
Cocaine abuse has been associated with vasculitis and stroke, and is suspected to influence the progression of AIDS dementia. Cocaine may enhance HIV-1 neuroinvasion by actions directed at the blood-brain barrier. HIV-1 appears to penetrate the human brain microvascular endothelial cell barrier by a paracellular route breached by tumor necrosis factor- $\alpha$ (TNF- $\alpha$ ). Cocaine's effects on the blood-brain barrier were investigated using human brain microvascular endothelial cells and peripheral blood monocytes. Cocaine $\left(10^{-5} \mathrm{M}\right.$ and $\left.10^{-6} \mathrm{M}\right)$ increased molecular permeability of the barrier and viral invasion by the macrophage-tropic HIV-1 $1_{\mathrm{IR}-\mathrm{FL}}$ into the brain chamber. Cocaine also augmented apoptosis of brain endothelial cells and monocytes, increased secretion of four chemokines (interleukin-8, interferon-inducible protein-10, macrophage inflammatory protein-1 $\alpha$, and monocyte chemoattractant protein1) and the cytokine, TNF- $\alpha$, by human monocytes. TNF- $\alpha$ enhanced invasion of the brain compartment by macrophage-tropic, lymphotropic, and bitropic HIV-1 strains. These data indicate that HIV-1 neuroinvasion can be increased by (a) cocaine's direct effects on brain microvascular endothelial cells and (b) paracrine effects of cocaine-induced pro-inflammatory cytokines and chemokines on the blood-brain barrier.
\end{abstract}

Keywords: cocaine; HIV-1; apoptosis; endothelial cells; tumor necrosis factor- $\alpha$; macrophage inflammatory protein-1 $\alpha$; monocyte chemoattractant protein-1

\section{Introduction}

Immunological consequences of cocaine abuse on the blood-brain barrier (BBB) are poorly understood, but appear significant since cocaine abuse is associated with vasculitis (Mody et al, 1988; Daras et al, 1994), suggesting an enhancement in leukocyte migration through endothelial barriers. Cocaine abuse is also accompanied by changes detected by brain imaging, indicating a defect in the BBB (Holman et al, 1992; Strickland et al, 1993). Cocaine may induce brain damage by its toxicity to neurons, as shown in vitro by synergy with HIV-1 (Koutsilieri et al, 1997), and by enhancement of HIV-1 replication in mononuclear cells (Bagasra and Pomerantz, 1993). The importance of drug abuse

Correspondence: M Fiala, M.D.

Received 7 April 1998; revised 26 June 1998; accepted 23 July 1998 in the AIDS epidemic is highlighted by a recent report noting the history of drug abuse in a majority of HIV-1 infected persons, including those with HIV-1 encephalitis who were autopsied by the Medical Examiner of New York City (Kibayashi et al, 1996). However, epidemiological studies of cocaine's role in AIDS dementia have produced highly variable results in different populations (Bacellar et al, 1994; Wellman, 1992; Handelsman et al, 1992). This discrepancy may, in part, be a reflection of the variability of cocaine's immunomodulating effects on induction of pro-inflammatory cytokines and chemokines (Fiala et al, 1996a).

Our previous work indicated that: (a) in cocaineaddicted individuals, cocaine infusion has divergent effects of secretion of pro-inflammatory cytokines, which appear to be heterogeneous for mononuclear cells from different donors, with inhibitory effects seen in macrophages and stimu- 
latory effects in lymphocytes, and (b) tumor necrosis factor- $\alpha$ (TNF- $\alpha$ ) increases HIV-1 penetration across a human BBB model (Fiala et al, 1996a). We have recently shown that in vivo cocaine infusion stimulates secretion of interferon- $\gamma$ (IFN$\gamma$ ), and probably TNF- $\alpha$, in mononuclear cells of a majority of addicted subjects (Gan X-H et al, 1998 (manuscript submitted)), and have demonstrated that TNF- $\alpha$ does indeed increase HIV-1 penetration across a human BBB model (Fiala et al, 1997). We have also shown that cocaine enhances monocyte migration across human brain microvascular endothelial cells (BMVEC) in the BBB model. These effects of cocaine appear to be mediated by increased expression of cell adhesion molecules (Gan X-H et al, 1998 (manuscript submitted)). Taken together, the data suggest that cocaine may increase HIV-1 neuroinvasion by its effect on migration of virus-infected monoyctes, and by induction of TNF- $\alpha$ and other pro-inflammatory cytokines which can open the blood-brain barrier to cell-free virus. The data presented in this report demonstrate cocaine's stimulatory effects on apoptosis of brain endothelial cells and monocytes, and on induction of chemokines and pro-inflammatory cytokines, such as TNF- $\alpha$, which can modify the integrity of the BBB and increase HIV-1 neuroinvasion.

\section{Results}

We have shown that cocaine can induce adhesion molecules, and enhance transendothelial migration of leukocytes (Gan X-H et al, 1998 (manuscript submitted)), which may disturb the function of the BBB. The in vivo effects of cocaine on the BBB could also be mediated by cocaine's direct actions on endothelial cells, and by paracrine responses to cytokines induced by cocaine. We have, therefore, investigated cocaine's effects on endothelial cell permeability and apoptosis as well as cocaine's induction of chemokines and cytokines.

Cocaine's enhancement of endothelial permeability Experiments in the in vitro BBB model demonstrated that cocaine has direct effects on BMVEC permeability. Treatment of the BBB model with cocaine $\left(10^{-5} \mathrm{M}\right.$ to $\left.10^{-6} \mathrm{M}\right)$ resulted in a significant dose-dependent increase in permeability to both inulin and dextran (Figure 1).

\section{Cocaine's induction of apoptosis}

Cocaine has previously been reported to induce apoptosis of thymocytes (Wu et al, 1997). We examined cocaine's induction of apoptosis in cultures of BMVEC and in monocytes using an enzyme-linked immunosorbent assay (ELISA) of generated nucleosomes. As shown in Figure 2, cocaine induced apoptosis in both cell types in a

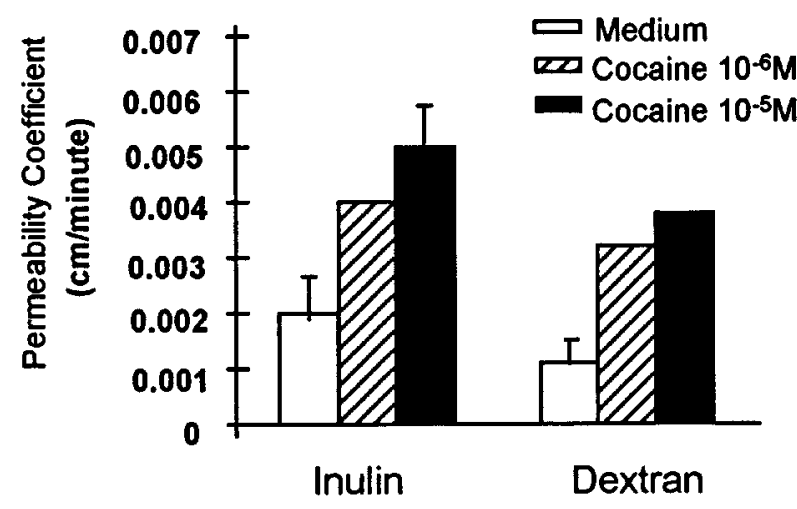

Figure 1 Effect of cocaine on permeability of the BBB model. Replicate models were treated for $4 \mathrm{~h}$ with cocaine at the indicated concentration in the medium of the upper chamber. After $4 \mathrm{~h}$, the coefficient of permeability was determined using $\left[{ }^{14} \mathrm{C}\right]$-methylated inulin (M.W. 5000) or ${ }^{14} \mathrm{C}$-labeled dextran (M.W. 70 000) (Sigma Chemical Company, St. Louis, MO, USA) as described in Materials and methods.
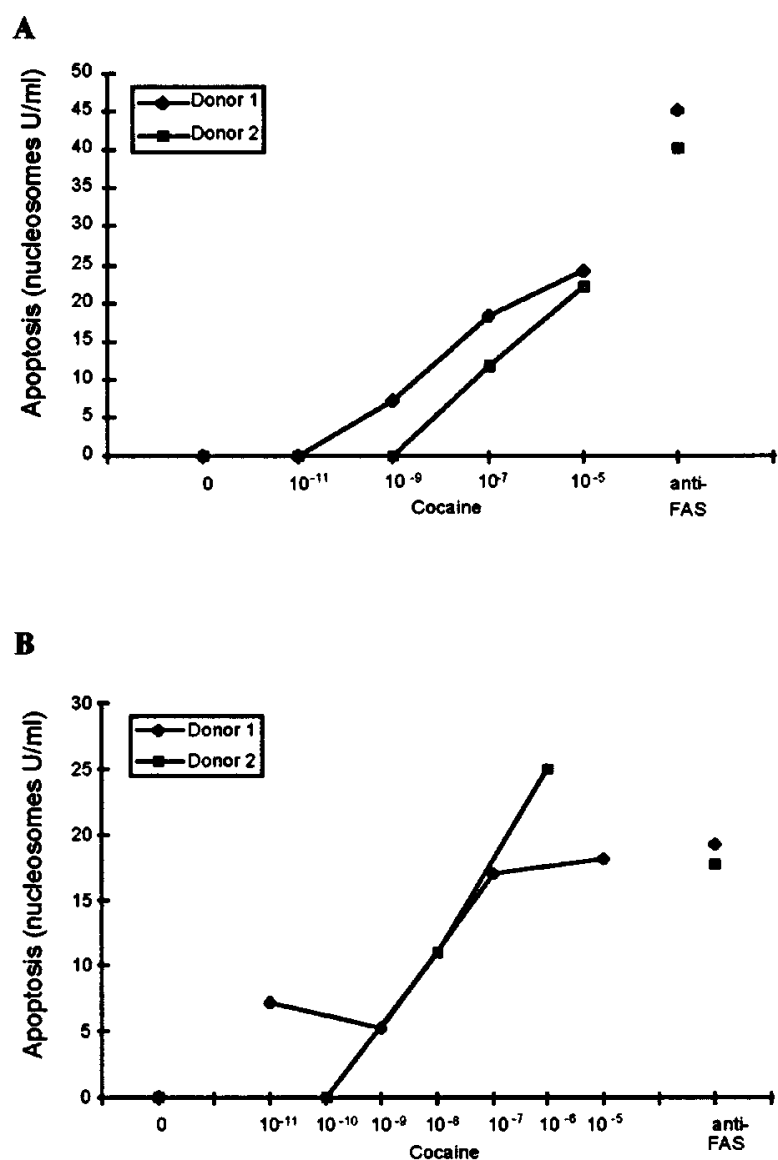

Figure 2 Cocaine's effects on induction of apoptosis in (A) brain endothelial cells, and (B) monocyte cultures. BMVEC or peripheral monocytes were incubated in presence of indicated concentrations of cocaine for $24 \mathrm{~h}$ at $37^{\circ} \mathrm{C}$. Apoptosis was evaluated using a Nucleosome ELISA kit (Oncogene Research Products, Cambridge, MA 021420, USA) as described in Materials and methods. 
dose-dependent fashion. The effect of $10^{-5} \mathrm{M}$ cocaine on apoptosis of monocytes was comparable to that seen following an anti-FAS antibody response.

Cocaine's enhancement of chemokine secretion by monocytes

In preliminary experiments, we showed, in the BBB model, that the chemokines normally expressed and secreted by T-cells upon activation, RANTES, interleukin-8 (IL-8) and macrophage inflammatory protein-2 (MIP-2), strongly attract monocyte transmigration into the lower chamber of the model, and increase ionic permeability. Medium containing MIP-2 (50 ng/ml), a chemokine previously shown to cause a severe breach in the BBB (Bell et al, 1996), decreased electrical resistance in the model by $35 \%$. We have now examined cocaine's induction of two C-X-C chemokines, IL-8 and interferoninducible protein-10 (IP-10), and two C-C chemokines, macrophage inflammatory protein- $1 \alpha$ (MIP$1 \alpha$ ) and monocyte chemoattractant protein-1 (MCP$1)$, which were shown to be chemoactive in the murine central nervous system (Bell et al, 1996).
Cocaine $\left(10^{-9} \mathrm{M}-10^{-6} \mathrm{M}\right)$ induced secretion of the two C-X-C chemokines, IP-10 and IL-8, and the two C-C chemokines, MIP- $1 \alpha$ and MCP-1, into the supernatant of 48-h monocyte cultures, while higher cocaine concentrations $\left(10^{-5} \mathrm{M}-10^{-4} \mathrm{M}\right)$ inhibited secretion, so as to produce a bell-shaped doseresponse profile (Figure 3). However, using monocytes from two other donors, cocaine was found to up-regulate MIP-1 $\alpha$, MCP-1, IP-10 and IL-8 secretion at the higher cocaine concentrations $\left(10^{-4} \mathrm{M}-\right.$ $10^{-5} \mathrm{M}$ ) (data not shown).

\section{Cocaine's enhancement of TNF- $\alpha$ secretion by} monocytes

TNF- $\alpha$ plays a crucial role in AIDS dementia by stimulating HIV-1 expression in microglia (Chao et al, 1994) and macrophages (Poli and Fauci, 1992), reactivating HIV-1 infection in astrocytes (Fiala et al, 1996b), inducing astrocytosis (Wilt et al, 1995) and damaging the BBB. The effects of cocaine in HIV dementia may be mediated, in part, through TNF- $\alpha$. Cocaine treatment of monocytes increased secretion of TNF- $\alpha$ in a dose-responsive fashion $\left(10^{-5} \mathrm{M}-10^{-9} \mathrm{M}\right)$ and potentiated the effects of LPS
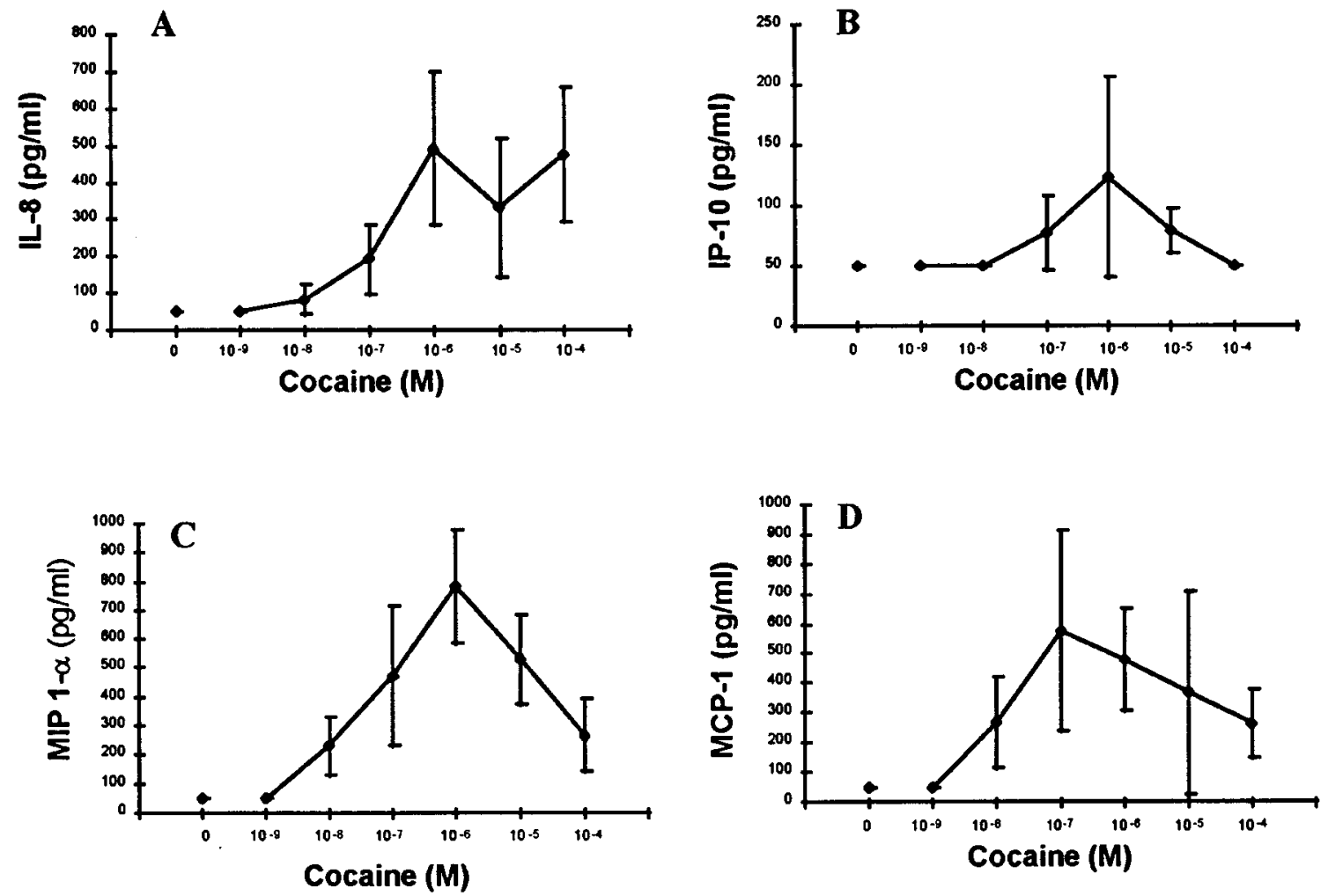

Figure 3 Cocaines effects on C-X-C chemokines (IL-8 and IP-10) and C-C chemokines (MIP- $\alpha$ and MCP-1) secretion by peripheral blood monocytes. Monocytes (400 000), suspended in RPMI 1640 with $10 \%$ autologous serum with or without cocaine at the indicated concentration, were incubated for $48 \mathrm{~h}$. The supernatant medium was collected and stored frozen until the ELISA assay as described in Materials and methods. The results are expressed in $\mathrm{pg} / \mathrm{ml}$. 
on monocyte TNF- $\alpha$ secretion twofold over baseline (Figure 4).

\section{Enhancement of HIV-1 penetration across human} $B M V E C$ by $T N F-\alpha$ or cocaine

Previously, using the in vitro BBB model, we showed that the HIV-1 $1_{\text {IR-FL }}$ strain penetrates the BMVEC/astrocyte bilayer via a paracellular route opened by TNF- $\alpha$ (Fiala et al, 1997). The effect of TNF- $\alpha$ is dose-dependent without an apparent

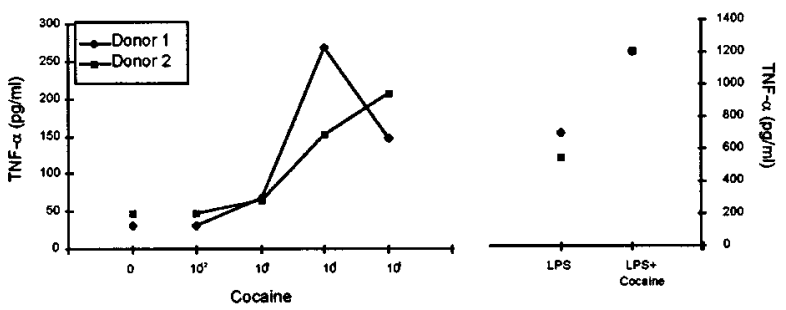

Figure 4 Effect of cocaine on TNF- $\alpha$ secretion by peripheral blood monocytes. Peripheral monocytes (400 000) from two donors were incubated in RPMI 1640 medium with 5\% fetal calf serum for $24 \mathrm{~h}$ in the presence of various concentrations of cocaine or LPS. At the completion of the incubation, TNF- $\alpha$ concentration in the supernatant medium was determined by the ELISA assay as described in Materials and methods. threshold in the range of $1-100 \mathrm{ng} / \mathrm{ml}$. The significance of this finding to human disease could be substantial if it is also found to occur with other HIV-1 strains. We, therefore, examined the effects of TNF- $\alpha$ on HIV-1 invasion in the BBB model using four different HIV-1 strains. Without treatment, the model functioned as a tight barrier against HIV-1, retaining approximately $99.5 \%$ of the viral RNA copies for $24 \mathrm{~h}$.

TNF- $\alpha$ treatment enhanced the penetration of all strains tested: JR-FL, a monocytotropic strain, increased 5.6-fold; ADA, a monocytotropic strain, increased 2.2-fold; a 5.9-fold increase was seen with the 89.6, a dual-tropic strain; and IIIB, a lymphotropic strain, increased 3.8-fold (Table 1).

Cocaine $\left(10^{-5} \mathrm{M}\right)$ treatment alone enhanced penetration of the $\mathrm{HIV}_{\mathrm{JR}-\mathrm{FL}}$ strain into the brain chamber up to 8.4-fold when replicate BBB models were treated for $24 \mathrm{~h}$ or $48 \mathrm{~h}$ (Table 2).

\section{Discussion}

Route of HIV-1 invasion across the human BMVEC/ astrocyte barrier

Our experiments in the human BBB model are designed to experimentally study possible routes and molecular mechanisms of HIV-1 invasion across the $\mathrm{BBB}$, and the role of factors, such as

Table 1 Effect of TNF- $\alpha$ on penetration of HIV-1 strains across the blood-brain barrier model.

\begin{tabular}{|c|c|c|c|c|}
\hline$H I V-1$ strain & $\begin{array}{l}\text { Strain } \\
\text { classification }\end{array}$ & $\begin{array}{l}\text { Virus inoculum in upper } \\
\text { chamber (RNA copies) }\end{array}$ & $\begin{array}{r}\text { Virus penetration } \\
\text { without } T N F-\alpha \\
\text { (RNA }\end{array}$ & $\begin{array}{l}\text { lower chamber } \\
\text { with TNF- } \alpha \\
\text { es) }\end{array}$ \\
\hline JR-FL & $\begin{array}{l}\text { Monocytotropic } \\
\text { R5, R3, STRL33 }\end{array}$ & 1065488 & $1574 \pm 127^{\mathrm{b}}$ & $8856 \pm 1478^{b}$ \\
\hline $\mathrm{ADA}$ & $\begin{array}{l}\text { Monocytotropic } \\
\text { R5, R3, STRL33 }\end{array}$ & 1575826 & 31096 & 67212 \\
\hline IIIB & $\begin{array}{l}\text { Lymphotropic } \\
\text { X4 }\end{array}$ & 783361 & 10144 & 38920 \\
\hline 89.6 & $\begin{array}{l}\text { Dual-tropic } \\
\text { X4, R2b, R3, R5 }\end{array}$ & 1017000 & $15840 \pm 5059^{b}$ & $94498 \pm 25718^{b}$ \\
\hline
\end{tabular}

${ }^{\mathrm{a}}$ Replicate blood-brain barrier models were pre-treated with TNF- $\alpha$ or control medium for $4 \mathrm{~h}$, when each HIV-1 strain was placed in the upper chamber at the indicated dose. After $24 \mathrm{~h}$, an aliquot was removed from the lower chamber and the amount of virus was determined by the HIV-1 RNA assay. ${ }^{b}$ Mean and s.e.m. of duplicate models.

Table 2 Effect of cocaine on penetration of macrophage-tropic HIV-1 $1_{\text {RR-FL }}$ strain across the BBB model.

\begin{tabular}{|c|c|c|c|}
\hline \multirow[b]{2}{*}{$\begin{array}{l}\text { Virus inoculum in upper } \\
\text { chamber (RNA copies) }\end{array}$} & \multirow[b]{2}{*}{$\begin{array}{l}\text { Pre-treatment of the } \\
\text { upper chamber }\end{array}$} & \multicolumn{2}{|c|}{ Virus penetration into lower chamber } \\
\hline & & $24 h$ & (RNA copies) $\quad 48 \mathrm{~h}$ \\
\hline 1065488 & Medium & $1574+126^{\mathrm{b}}$ & $31948+1384^{\mathrm{b}}$ \\
\hline 1065488 & Cocaine $\left(10^{-5} \mathrm{M}\right)$ & $13176+4449^{b}$ & $74398+8595^{\mathrm{b}}$ \\
\hline
\end{tabular}


cocaine, in AIDS. Early after the primary HIV-1 infection, the individual's plasma contains enormous concentrations of cell-free HIV-1 (Piatak et al, 1993). HIV-1 RNA levels in the cerebrospinal fluid (CSF) appear to correlate with those in the plasma (Ellis et al, 1997; McArthur et al, 1997; Roberston et al, 1998). This relationship, however, was observed by Ellis et al. (1997) in subjects with CD4+ counts $>200 / \mathrm{mm}^{3}$, whereas McArther et al (1997) found this correlation in those with counts $<200 / \mathrm{mm}^{3}$, and Roberston et al (1998) noted this correlation in patients at various stages of HIV disease. The role of HIV-1-infected CD4+ lymphocytes in the pathogenesis of early HIV-1 encephalitis (Massari et al, 1990) is supported by early stagespecific lymphocytic pleocytosis (McArthur et al, 1989; Elovara et al, 1988) and perivascular lymphocytic infiltrates in the brain (Gray et al, 1992). The virus in the CSF of the subjects examined by Ellis et al (1997) was, however, cell-free virus. A previous study also noted that HIV-1 isolated from the CSF was found in the supernatant rather than in the cellular fraction (Spector et al, 1993) suggesting that the CSF/plasma relationship is attributable to cellfree virus, and might be indirectly related to lymphocytic pleocytosis.

As demonstrated previously and herein, cell-free macrophage-, lympho- and bi-tropic HIV-1 strains can penetrate across an in vitro endothelial barrier using a route opened by TNF- $\alpha$. This response to TNF- $\alpha$ is specific to human endothelial cells, specifically tight brain microvascular endothelial cells. Other endothelial cells present a weaker barrier to HIV-1 penetration, and astrocytes present no significant barrier to penetration (Fiala et al, 1997). Most viral isolates in early infection are macrophage-tropic; yet our human BMVEC were not susceptible to infection with a macrophagetropic HIV-1 $1_{\mathrm{IR}-\mathrm{FL}}$ strain (Fiala et al, 1997). Other investigators have shown HIV-1 infection of human BMVEC, but only by lymphotropic strains (Moses et al, 1993). These observations would argue against HIV-1 infection of BMVEC as a mechanism of early neuroinvasion analogous to the simian immunodeficiency virus (SIV) infection of the simian brain endothelial cells (Edinger et al, 1997). Nevertheless, using a combination of in situ DNA polymerase reaction, reverse transcriptase-initiated in situ PCR and immunohistochemistry, HIV-1 mRNA expression was demonstrated within microvascular endothelial and choroid plexus cells in the brain from AIDS dementia patients (Bagasra et al, 1996), suggesting that the endothelial cells can be infected by lymphotropic strains in neuro-AIDS.

The paracellular route opened by TNF- $\alpha$ and possibly cocaine for cell-free plasma virus could be of considerable significance for HIV-1 neuroinvasion in early HIV-1 disease. Additionally, lymphocytes could be major participants in early neuroinvasion, indirectly mediating an opening in the BBB during lymphocyte migration, which could be augmented by cocaine's enhancement of the transendothelial migration of leukocytes (Gan X-H et al, 1998 (manuscript submitted)). In late HIV-1 disease, in patients with AIDS dementia, the 'Trojan horse' transport of HIV-1 by monocytes and T lymphocytes is believed to be the major route of neuroinvasion (Gendelman et al, 1997), which could also be augmented by cocaine. These different mechanisms may overlap in successive stages of AIDS, as reflected by a gradual increase in immune stimulation noted in the CSF (Gisslén et al, 1994).

\section{Role of cocaine in cell-free HIV-1 invasion across} the human BMVEC barrier

Similar to TNF- $\alpha$, cocaine was shown to increase HIV-1 penetration across the BBB model. Cocaine's effects on the BBB appear complex including both direct, pro-apoptotic effects on endothelial cells, and indirect effects mediated by chemokines and cytokines. Although the relative significance of these molecular mechanisms for HIV-1 neuroinvasion is not established, TNF- $\alpha$ may play a critical role in cocaine's actions since it was shown to open the BBB for all macrophage-tropic, T-cell-tropic and bi-tropic HIV-1 strains. In addition, cocaine's direct effects on BMVEC may help to clear the way for $\mathrm{HIV}-1_{\mathrm{JR}-\mathrm{FL}}$ penetration.

\section{Role of chemokines induced by cocaine and chemokine receptors in HIV-1 invasion}

Cocaine stimulates human monocytes to secrete chemokines, some of which breach the BBB in vivo, as demonstrated by horseradish peroxidase staining (Bell et al, 1996). The potential role of chemokine receptors in retroviral neuroinvasion has recently produced considerable interest. SIV infection of simian brain endothelial cells was shown to be mediated via a chemokine receptor CCR5-dependent mechanism, which was inhibited by the CCR5 ligand, RANTES (Edinger et al, 1997). The C-C chemokines, RANTES, MIP- $1 \alpha$, and MIP- $1 \beta$, were initially hailed as potential therapeutic agents for AIDS (Cocchi et al, 1995). Their role, however, appears to be cell-type dependent-inhibitory to primary strains in $\mathrm{T}$ lymphocytes and stimulatory in macrophages (Schmidtmayerova et al, 1996). The major physiological role for the chemokines is as participants in the inflammatory response, aiding leukocyte trafficking across the vascular wall. The part that chemokines play in HIV-1 neuroinvasion may, therefore, be a double-edged sword. Chemokines could block chemokine receptors, which are putative HIV co-receptors, on brain endothelial cells, but they could also open the BBB to HIV-1 invasion.

Cocaine is considered a significant co-factor in AIDS, but its mechanisms are poorly understood. Since cocaine was shown to induce monocytic secretion of two C-X-C and two C-C chemokines, 
as well as TNF- $\alpha$, and inasmuch as chemokines can breach the BBB in vivo, as shown by horseradish peroxidase staining (Bell et al, 1996), it seems likely that cocaine can have a significant impact on HIV-1 neuroinvasion.

\section{Materials and methods}

\section{Chemicals}

(-)-cocaine was provided by the Research Triangle Institute (Research Triangle Park, NC, USA) through the Research Technology Branch of the National Institute on Drug Abuse, and was found to be negative (less than $10 \mathrm{pg} / \mathrm{ml}$ ) for endotoxin by the Limulus Lysate Test (Sigma, St. Louis, MO, USA).

\section{Cell culture and peripheral blood monocytes}

The human blood-brain barrier model was constructed using adult human brain microvascular endothelial cells and human astrocytes on opposite sides of a porous Cyclopore membrane coated with collagen I and fibronectin (Collaborative Biomedical Products, Bedford, MA, USA) and cultured in DME/F12 (Irvine Scientific, Santa Ana, CA, USA), with $10 \%$ fetal calf serum and endothelial cell growth supplement (Upstate Biotechnology, Lake Placid, NY, USA) as described previously. Human brain microvascular endothelial cells were prepared from adult cortical tissues obtained during surgery (Fiala et al, 1997).

Human monocytes were separated from the elutriated peripheral blood of leukopheresed healthy volunteers who had provided informed consent under a protocol approved by the Institutional Review Board. The mononuclear cells were subsequently passed through a continuous Percol gradient to enrich for $\mathrm{CD} 14^{+}, \mathrm{CD} 3^{-}, \mathrm{CD}^{+} 6^{+}, \mathrm{CD} 19^{+}$ mononuclear cells. The monocyte preparations were greater than $90 \%$ monocytes flow cytometry. Monocytes by were cultured in RPMI 1640 with $10 \%$ autologous serum with or without cocaine for $48 \mathrm{~h}$ for the chemokine assays, or for $24 \mathrm{~h}$ for the TNF- $\alpha$ assay. At the endpoints, the medium was separated by brief centrifugation and frozen at $-70^{\circ} \mathrm{C}$ until the ELISA assay was performed.

\section{Virus strains}

HIV-1 strains were classified on the basis of their use of chemokine receptors as proposed recently (Berger et al, 1998). The following HIV-1 strains were used: $\mathrm{HIV}_{\mathrm{IR}-\mathrm{FL}}$, a monocytotropic R5 (Deng et al, 1996), R3 (He et al, 1997) and STRL33 (Liao et al, 1997) strains $\left(1.06 \times 10^{11} \mathrm{RNA}\right.$ copies $\left./ \mathrm{ml}\right)$; ADA, a monocytotropic R5 (Deng et al, 1996), R3 (He et al, 1997) and STRL33 (Liao et al, 1997) strains $\left(1.26 \times 10^{11}\right.$ RNA copies/ml); 89.6, a dual-tropic X4, R2b, R3, R5 (Doranz et al, 1996),and STRL33 (Liao et al, 1997) strain $\left(2 \times 10^{11}\right.$ RNA copies $\left./ \mathrm{ml}\right)$; and IIIB, a T-cell tropic X4 virus (Feng et al, 1996) $\left(1.56 \times 10^{10}\right.$ RNA copies/ml). HIV $\mathrm{IR}-\mathrm{FL}$ stock was prepared in human cord umbilical cells, as described previously (Fiala et al, 1997), whereas the other strains were grown in normal human donor PBMC at the UCSD Center for AIDS Research.

HIV-1 RNA assay

HIV-1 RNA was quantitated in supernatants diluted 1:4 with PBS, using the Amplicor HIV Monitor Test, performed according to the manufacturer's suggested procedure (Fiala et al, 1997).

\section{Apoptosis assay}

Apoptosis quantitation was performed using the Nucleosome ELISA kit (Oncogene Research Products, Cambridge, MA, USA) which quantitates mono- and oligo-nucleosomes in treated cells by DNA affinity-mediated capture of free nucleosomes, followed by ELISA detection of the histone component. As positive controls, cells treated with antiFAS antibody or phorbol-12-myristate-13-acetate $(10 \mu \mathrm{g} / \mathrm{ml})$ (Calbiochem) with phytohemagglutinin A $(50 \mathrm{ng} / \mathrm{ml})$ were assayed. The extracts for ELISA testing were prepared by cell centrifugation at 1000 r.p.m. $(200 \times$ g), followed by resuspension of the cell pellet in lysis buffer. Sample diluent was added to the final concentration of $1 \times 10^{6} \mathrm{cells} / \mathrm{ml}$, and the cells were incubated for $30 \mathrm{~min}$ on ice, centrifuged at 3000 r.p.m. $(1500 \times \mathrm{g})$ for $10 \mathrm{~min}$ at $4{ }^{\circ} \mathrm{C}$, and the resulting lysate was frozen at $-20^{\circ} \mathrm{C}$. The Nucleosome ELISA was performed according to the manufacturer's instructions, and the Nucleosome standards $(10,3.3,1.1$ and $0.366 \mathrm{U} / \mathrm{ml})$ were run with each assay. The quantitation of nucleosomes was expressed in nucleosome units (One unit=number of nucleosomes from 444 UV-treated Daudi cells/ml).

\section{Molecular permeability}

Inulin permeability was measured by adding $\left[{ }^{14} \mathrm{C}\right]-$ methylated inulin (M.W. 5000) or ${ }^{14} \mathrm{C}$-labeled dextran (M.W. 70 000) (Sigma Chemical Company, St. Louis, MO, USA), to the upper chamber of the BBB model for $30 \mathrm{~min}$. Radioactivity was determined by scintillation counting in the lower chamber. The permeability coefficient was calculated using the formula:

$\{\mathrm{V} /(\mathrm{A} * \mathrm{D})\}^{*}\{\Delta \mathrm{R} / \Delta \mathrm{T}\}$ where $\mathrm{V}=$ volume of the receptor chamber $\left(1.0 \mathrm{~cm}^{3}\right), \quad A=$ area of the cell monolayer $\left(0.36 \mathrm{~cm}^{2}\right), \mathrm{D}=$ initial amount of the marker molecule in the donor chamber, $\Delta \mathrm{R} / \Delta \mathrm{T}=$ amount of the marker molecule in the receiver solution $(\Delta \mathrm{T}=4 \mathrm{~h})$.

\section{ELISA for chemokines and TNF- $\alpha$}

Human MIP-1 $\alpha$, MCP-1, IL-8, IP-10 and TNF- $\alpha$ levels were determined using Quantikine ELISA kits (R\&D Systems, Minneapolis, MN, USA), following the manufacturer's instructions. 


\section{Acknowledgements}

This work was supported by NIH grant, DA 10442, and a subcontract of NS 26126 to MF,

\section{References}

Bacellar H, Munoz A, Miller EN, Cohen BA, Besley D, Selnes OA, Becker JT, McArthur JC (1994). Temporal trends in the incidence of HIV-1 related neurologic diseases: Multi-center AIDS Cohort Study 1985-1992. Neurology 44: 1892-1900.

Bagasra O, Pomerantz RJ (1993). Human immunodeficiency virus type 1 replication in peripheral blood mononuclear cells in the presence of cocaine. I Infect Dis 168: $1157-1164$.

Bagasra O, Lavi E, Bobroski L, Khalili K, Pestaner JP, Tawadros R, Pomerantz RJ (1996). Cellular reservoirs of HIV-1 in the central nervous system of infected individuals: identification by the combination of in situ polymerase chain reaction and immunohistochemistry. Aids 10: $573-585$.

Bell MD, Taub DD, Perry VH (1996). Overriding the brain's intrinsic resistance to leukocyte recruitment with intraparenchymal injections of recombinant chemokines. Neuroscience 74: 283-292.

Berger EA, Doms RW, Fenyo EM, Korber BTM, Littman DR, Moore JP, Sattentau QJ, Schuitemaker H, Sodroski J, Weiss RA (1998). A new classification for HIV-1. Nature 391: 240.

Chao CC, Gekker G, Sheng WS, Hu S, Tsang M, Peterson $P K$ (1994). Priming effect of morphine on the production of tumor necrosis factor- $\alpha$ by microglia: implications in respiratory burst activity and human immunodeficiency virus-1 expression. J Pharmacol Exp Ther 269: 198-203.

Cocchi F, DeVico AL, Garzino-Demo A, Arya SK, Gallo $\mathrm{RC}$, Lusso P (1995). Identification of RANTES, MIP-1 $\alpha$ and MIP- $1 \beta$ as the major HIV-suppressive factors produced by CD8+ T cells. Science 270: 1811-1815.

Daras M, Tuchman AJ, Koppel BS, Samkoff LM, Weitzner I, Marc J (1994). Neurovascular complications of cocaine. Acta Neurologica Scandinavica 90: $124-129$.

Deng HK, Liu R, Ellmeier W, Choe S, Unumatz D, Burkhart M, DiMarzio P et al (1996). Identification of a major co-receptor for primary isolates of HIV-1. Nature 381: $661-666$.

Doranz BJ, Rucker J, Yi Y, Smyth RJ, Samson M, Peiper SC, Parmentier M, Collman RG, Doms RW (1996). A dual-tropic primary HIV-1 isolate that uses fusin and the beta chemokine receptors CKR5, CKR4 and CKR2b as fusion co-factors. Cell 85: $1149-1158$.

Edinger AL, Mankowski JL, Doranz BJ, Margulies BJ, Lee B, Rucker J, Sharron M, Hoffman TL, Berson JF, Zink MC, Hirsch VM, Clements JE, Doms RW (1997). CD4independent, CCR5-dependent infection of brain capillary endothelial cells by a neurovirulent simian immunodeficiency virus strain. Proc Natl Acad Sci USA 94: $14742-14747$.
DA 07058 to SLC, and HL 48493 to MHW by the UCSD Center for AIDS Research, DAIDS 2 P30 AI36214.

Ellis RJ, Hsia K, Spector SA, Nelson JA, Heaton RK, Wallace MR, Abramson I, Atkinson JH, Grant I, McCutchan JA, HIV Neurobehavioral Research Center Group (1997). Cerebrospinal fluid human immunodeficiency virus type 1 RNA levels are elevated in neurocognitively impaired individuals with acquired immunodeficiency syndrome. Ann Neurol 42: 679688.

Elovaara I, Seppala I, Poutianen S, Sun J, Valle S-L (1998). Intrathecal humoral immunologic response in neurologically symptomatic and asymptomatic patients with human immunodeficiency virus infection. Neurology 38: 1451.

Feng Y, Broder CC, Kennedy PE, Berger CC (1996). HIV-1 entry cofactor: functional cDNA cloning of a seventransmembrane, G-protein-coupled receptor. Science 272: $872-877$.

Fiala M, Gan X-H, Newton T, Chiappelli F, Shapshak P, Kermani V, Kung MA, Diagne A, Martinez O, Graves M, Way D, Weinand M, Witte M (1996a). Divergent effects of cocaine on cytokine production by lymphocytes and monocyte/macrophages. Adv Exp Med Biol 402: $145-156$.

Fiala M, Rhodes RH, Shapshak P, Nagano I, Martinez OM, Diagne A, Baldwin G, Graves M (1996b). Regulation of HIV-1 infection in astrocytes: expression of Nef- $\alpha$ and IL-6 is enhanced in coculture of astrocytes with macrophages. J Neurovirol 2: 158166.

Fiala M, Looney DJ, Stins M, Way D, Zhang L, Gan X, Chiappelli F, Shapshak P, Weinand M, Graves M, Witte M, Kim K-S (1997). TNF- $\alpha$ opens a paracellular route for HIV-1 invasion across the blood-brain barrier. Molecular Medicine 3: 553-564.

Gendelman H, Persidsky Y, Ghorpade A, Limoges J, Stins M, Fiala M, Morrisett R (1997). The neuropathogenesis of the AIDS dementia complex. AIDS 11 (suppl A): S35-S45.

Gisslén M, Chiodi F, Fuchs D, Norkrans G, Svennerholm B, Wachter H, Hagberg L (1994). Markers of immune stimulation in the cerebrospinal fluid during HIV infection: a longitudinal study. Scand J Infect Dis 26: 523-533.

Gray F, Lesces M-C, Keohane C, Paraire F, Marc B, Durignon M, Gherardi R (1992). Early brain changes in HIV infection: Neuropathological study of $11 \mathrm{HIV}$ seropositive, non-AIDS cases. J Neuropathol Exp Neurol 51: $177-185$.

Handelsman L, Aronson M, Maurer G, Wiener J, Jacobson J, Bernstein D, Ness HS, Lasonczy M, Song IS et al (1992). Neuropsychological and neurological manifestations of HIV-1 dementia in drug users. $J$ Neuropsych Clin Neurosci 4: 21-28. 
He J, Chen Y, Farzan M, Choe H, Ohagen A, Gartner S, Busciglio J, Yang X, Hofmann W, Newman W et al (1997). CCR3 and CCR5 are co-receptors for HIV-1 infection of microglia. Nature 385: 645-649.

Holman BL, Garada B, Johnson KA, Mendelson J, Hallring E, Teoh SK, Worth J, Navia B (1992). A comparison of brain perfusion SPECT in cocaine abuse and AIDS dementia complex. J Nuclear Medicine 33: 1312-1315.

Liao F, Alkhatib G, Peden KW, Sharma G, Berger EA, Farber JM (1997). STRL33, a novel chemokine receptor-like protein, functions as a fusion cofactor for both macrophage-tropic and T cell line-tropic HIV1. J Exp Med 185: 2015-2023.

Kibyashi K, Mastri AR, Hirsch CS (1996). Neuropathology of human immunodeficiency virus infection at different disease stages. Human Pathol 7: 637-642.

Koutsilieri E, Gotz ME, Sopper S, Sauer U, Demuth M, ter Meulen V, Riederer P (1997). Regulation of glutathione and cell toxicity following exposure to neurotropic substances and human immunodeficiency virus-1 in vitro. I Neurovirol 3: $342-349$.

Massari FE, Poli G, Schnittman SM, Psallidopoulos MC, Davey V, Fauci AS (1990). In vivo $T$ lymphocyte origin of macrophage-tropic strains of HIV. Role of monocytes during in vitro isolation and in vivo infection. I Immunol 144: 4628-4632.

McArthur JC, Sipos E, Cornblath DR, Welch D, Chupp M, Griffin DE, Johnson RT (1989). Identification of mononuclear cells in CSF of patients with HIV infection. Neurology 39: 66-70.

McArthur JC, McClernon DR, Cronin MF, Nance-Sproson TE, Saah AJ, St Clair M, Lanier ER (1997). Relationship between human immunodeficiency virus-associated dementia and viral load in cerebrospinal fluid and brain. Ann Neurol 42: 689-698.

Mody CK et al (1988). Neurologic complications of cocaine. Neurology 38: 1181-1183.

Moses AV, Bloom FE, Pauza CD, Nelson JA (1993). Human immunodeficiency virus infection of human brain capillary endothelial cells occur via a CD4/ galactosylceramide-independent mechanism. Proc Natl Acad Sci USA 90: 10474-10478.
Piatak Jr M, Saag MS, Yang LC, Clark SJ, Kappes JC, Luk KC, Hahn BC, Shaw GM, Lifson JD (1993). High levels of HIV-1 in plasma during all stages of infection determined by competitive PCR. Science 259: 17491754

Poli G and Fauci AS (1992). The role of monocyte/ macrophages and cytokines in the pathogenesis of HIV infection. Pathobiology 60: 246-251.

Robertson K, Fiscus S, Kappor C, Robertson W, Schneider G, Shepard R, Howe L, Silva S, Hall C (1998). CSF, plasma viral load and HIV associated dementia. J Neurovirol 4: 90-94.

Schmidtmayerova H, Sherry B, Bukrinsky M (1996). Chemokines and HIV replication. Nature, 382: 676.

Spector SA, Hsia K, Pratt D, Lathey J, McCutchan A, Alcara JE, Atkinson JH et al (1993). Virologic markers of human immunodeficiency virus type 1 in cerebrospinal fluid. J Infect Dis 168: $68-74$.

Strickland TL et al (1993). Cerebral perfusion and neuropsychological consequences of chronic cocaine use. J Neuropsych Clin Neurosci 5: 419-427.

Wellman MC (1992). Neuropsychological impairment among intravenous drug users in pre-AIDS stages of HIV infection. Int J Neurosci 64: 183-194.

Wilt SG, Milward E, Zhou JM, Nagasato K, Patton H, Rusten R, Griffen DE, O’Connor M, Dubois-Dalcq M (1995). In vitro evidence for a dual role of tumor necrosis factor- $\alpha$ in human immunodeficiency virus type 1 (HIV-1) encephalopathy. Ann Neurol 37: 381394.

Wu Y-B, Shen M-L, Gu GG, Anderson KM, Ou DW (1997). The effects of cocaine injections on mouse thymocyte population. Proc Soc Exp Biol Med 214: $173-176$. 